\title{
ESTIMASI KEDALAMAN BATUAN DASAR MENGGUNAKAN METODA GEOLISTRIK TAHANAN JENIS KONFIGURASI DIPOLE-DIPOLE DI UNIVERSITAS NEGERI PADANG KAMPUS AIR TAWAR
}

\author{
Media Febrina*), Akmam**) dan Fatni Mufit**) \\ *)Mahasiswa Jurusan Fisika FMIPA UNP, email: mediafebrina@ymail.com \\ **)Staf Pengajar Jurusan Fisika FMIPA UNP, email: akmamdatuk@ gmail.com, \\ fatni.mufit@gmail.com
}

\begin{abstract}
Estimation of basement rocks depth has been done in Padang State University, Air Tawar campus. The research that uses Dipole-dipole resistivity geoelectrical method was aimed to determine the depth, resistivity value and the kinds of basement rocks. Data were collected by Ares Multielectrode in 4 lines. Processing of data was done using Res2dinv software with Robust Constraint inversion and it results $2 D$ model of earth's surface that consists of depth and resistivity value. The result of this research shows that there are basement rocks around sounding point $00^{\circ} 53^{\prime} 44,0^{\prime \prime} \mathrm{S}$ and $100^{\circ} 20^{\prime} 79,8^{\prime \prime} \mathrm{E}$ in $1^{\text {st }}$ line and sounding point $00^{\circ} 53^{\prime} 53,1$ ' $S$ and $100^{\circ} 21^{\prime} 02,8^{\prime \prime} \mathrm{E}$ in $2^{\text {nd }}$ line at depth of more than $25,2 \mathrm{~m}$ with resistivity value $513-622 \Omega m$ and $632-2150 \Omega m$. Basement rocks are also found in $3^{\text {rd }}$ line around sounding point $00^{\circ} 53^{\prime} 48,9$ ' $S$ dan 100 $20^{\prime} 50,6^{\prime \prime} E$ at depth of more than $21,85 \mathrm{~m}$ with resistivity value 596,5 - $734 \Omega \mathrm{m}$, while $4^{\text {th }}$ line at sounding point $00^{\circ} 53^{\prime} 55,7{ }^{\prime \prime} S$ and $100^{\circ} 21^{\prime} 02,3$ 'E did not find basement rocks. Possibility of basement rocks in $4^{\text {th }}$ line are at depth of more than 29,5 m. Basement rocks that are found in this research is interpreted as Andesite. Information about basement rocks can be used for construction planning in Padang State University, Air Tawar campus.
\end{abstract}

Keywords: basement rocks, resistivity geoelectrical method, Dipole-dipole, Padang State University

\section{PENDAHULUAN}

Batuan dasar merupakan batuan yang paling tua diantara batuan yang ada di sekitar wilayahnya. Batuan dasar memiliki sifat yang kompak pada lapisan bawah, sementara pada lapisan atas cenderung mengalami pelapukan. Proses pelapukan yang terjadi pada lapisan atas batuan dasar akan membentuk lapisan batuan baru. Lapisan batuan baru tersebut juga akan mengalami pelapukan sehingga terbentuk jenis batuan yang lain. Berdasarkan sifat tersebut diketahui bahwa batuan dasar dapat menjadi dasar bagi jenis-jenis batuan yang berada di atas lapisannya sehingga keberadaan batuan dasar dapat menjadi salah satu acuan dalam studi tentang struktur batuan di suatu daerah.
Kota Padang merupakan wilayah yang sering terjadi gempabumi dengan kekuatan lebih dari 5 SR, bahkan pada tanggal 30 September 2009 terjadi gempabumi dengan kekuatan 7,6 SR. Menurut Moch (1995: 143), “Gempabumi yang dasyat akan mengakibatkan berubahnya susunan lapisan bumi”. Berdasarkan hal tersebut diperkirakan bahwa gempabumi yang sering terjadi di Kota Padang dapat menyebabkan berubahnya struktur batuan, termasuk batuan dasar. Mengingat pentingnya fungsi Universitas Negeri Padang (UNP) kampus Air Tawar untuk kemajuan bangsa serta seringnya terjadi aktivitas tektonik di wilayah ini, perlu dilakukan penelitianpenelitian tentang Kebumian baik bidang 
Geofisika maupun bidang Geologi, salah satunya penelitian tentang keberadaan batuan dasar.

Keberadaan dan jenis batuan dasar di UNP kampus Air Tawar belum diketahui. Mengingat UNP kampus Air Tawar masih dalam tahap pembangunan, maka informasi tentang keberadaan dan jenis batuan dasar sangat dibutuhkan. Informasi tersebut dapat menjadi salah satu pertimbangan dalam perencanaan pembangunan di UNP kampus Air Tawar. Oleh karena itu dilakukan penelitian untuk mengetahui kedalaman, nilai tahanan jenis dan jenis batuan dasar yang terdapat di UNP kampus Air Tawar.

Menurut Hanang (2008:279), "Batuan dasar adalah batuan yang tersingkap di sekitar gunung api dan bertindak sebagai alas dari aneka jenis batuan yang dihasilkan oleh gunung api tersebut". Batuan dasar memiliki nilai tahanan jenis yang cukup tinggi. Hal ini disebabkan karena batuan dasar memiliki porositas dan permeabilitas yang sangat rendah. Menurut Sircar (2004:148), "Batuan dasar memiliki nilai porositas mendekati nol", sementara menurut Gutmanis (2010: 4), "Nilai permeabilitas batuan dasar adalah kecil dari 0,5\%".

Batuan dasar yang dimiliki setiap daerah berbeda satu sama lainnya tergantung pada sejarah geologi daerah tersebut sehingga batuan dasar dapat berupa batuan beku, batuan sedimen maupun metamorf. Keberadaan batuan dasar dapat diperkirakan menggunakan metoda geolistrik tahanan jenis.

Metoda geolistrik tahanan jenis mempelajari sifat tahanan jenis listrik pada lapisan batuan di bawah permukaan bumi. Arus listrik dialirkan ke bawah permukaan bumi melalui elektroda arus listrik, kemudian beda potensial yang terjadi diukur melalui elektroda potensial. Tahanan jenis batuan di bawah permukaan bumi dapat dihitung dari hasil pengukuran arus listrik dan beda potensial.

Menurut Akmam (2004: 596), "Secara umum tahanan jenis bumi tidak homogen, berarti tahanan jenis yang terhitung adalah tahanan jenis semu (apparent resitivity, $\boldsymbol{\rho}_{a}$ )". Tahanan jenis semu $\boldsymbol{\rho}_{\boldsymbol{a}}$ dapat ditentukan menggunakan Persamaan (1).

dimana

$$
\rho_{a}=K \frac{\Delta V}{I}
$$

$$
K=2 \pi\left\{\left(\frac{1}{r_{1}}-\frac{1}{r_{2}}\right)-\left(\frac{1}{r_{3}}-\frac{1}{r_{4}}\right)\right\}^{-1}
$$

$\Delta \boldsymbol{V}$ dan $\boldsymbol{I}$ menyatakan beda potensial dan arus listrik yang terukur, sementara $\boldsymbol{K}$ menyatakan faktor geometri yang bergantung pada konfigurasi elektroda. Penelitian ini menggunakan konfigurasi Dipole-dipole. Jarak antara elektroda arus dengan jarak antara elektroda potensial pada konfigurasi ini adalah sama yaitu sebesar a. Susunan elektroda pada konfigurasi Dipole-dipole dapat dilihat pada Gambar 1 berikut:

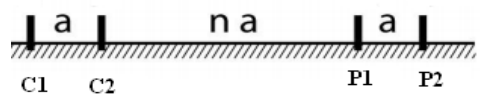

Gambar 1. Susunan Elektroda pada Konfigurasi Dipole-dipole (Marescot. 2009:44)

Konfigurasi Dipole-dipole dapat mencapai kedalaman yang lebih dalam dibandingkan dengan konfigurasi Wenner, Schlumberger dan Square (Reynolds. 1997: 433). Berdasarkan Gambar 1 tahanan jenis semu konfigurasi Dipole-dipole dapat ditentukan menggunakan Persamaan (3).

$$
\rho_{a}=\pi n(n+1)(n+2) a \frac{\Delta V}{I}
$$

Data hasil pengukuran pada penelitian ini dianalisis menggunakan inversi Robust Constraint. Li et al (2009:5) menyatakan persamaan inversi Robust pada Persamaan (4).

$$
\ddot{y}=\widehat{\varnothing}(x, \boldsymbol{u})+\Delta_{\text {inv }}(\boldsymbol{x}, \boldsymbol{u})
$$

dimana $\boldsymbol{u}=\widehat{\emptyset}^{-1}(\boldsymbol{x}, \boldsymbol{\sigma})$ adalah pengontrol inversi dan $\boldsymbol{x}$ merupakan vektor state dan $\boldsymbol{y}$ merupakan output yang mengandung dua parameter yaitu kedalaman dan tahanan jenis. $\sigma$ menyatakan input pengontrol pseudo dari sistem inversi. Pengontrol 
inversi $\boldsymbol{u}$ dari persamaan (4) dapat dinyatakan dengan Persamaan (5).

$$
u=B^{-1}(x)\left[\ddot{y}_{c}-A_{1}(x)\right]
$$

dimana $\boldsymbol{A}(\boldsymbol{x})$ dan $\boldsymbol{B}(\boldsymbol{x})$ adalah fungsi nonlinier dari $\boldsymbol{x}$.

Penelitian ini dilakukan di UNP

kampus Air Tawar, Kota Padang. Berdasarkan Geologi Kota Padang diketahui bahwa daerah Air Tawar didominasi oleh Alluvium (Dinas Energi dan Sumber Daya Mineral Provinsi Sumatera Barat. 2012). Alluvium merupakan batuan yang terdiri dari lanau, lempung, pasir, kerikil, pasir lempungan dan lempung pasiran yang berasal dari butiran batuan yang terendapkan oleh air mengalir, selain itu Alluvium juga merupakan hasil pelapukan dari batuan Andesite. Alluvium mempunyai nilai tahanan jenis 10-800 $\Omega \mathrm{m}$ (Telford et al, 1976:455).

Wilayah di sekitar UNP kampus Air Tawar juga terdapat air tanah (Groundwater). Tabel 1 menunjukkan kedalaman beberapa sumur air tanah yang terdapat di sekitar UNP kampus Air Tawar. Tabel 1. Data Kedalaman Sumur Air Tanah di Sekitar UNP Kampus Air Tawar.

\begin{tabular}{|r|l|l|}
\hline No & \multicolumn{1}{|c|}{ Lokasi } & \multicolumn{1}{c|}{ Kedalaman } \\
\hline 1. & Mushalla FIS & $6,0 \mathrm{~m}$ \\
\hline 2. & LPMP (dekat FT) & $9,0 \mathrm{~m}$ \\
\hline 3. & $\begin{array}{l}\text { Jl. Belibis Blok B } \\
\text { No. 14 (dekat FIK) }\end{array}$ & $6,0 \mathrm{~m}$ \\
\hline 4. & Jl. Hamka No. 20A & $8,0 \mathrm{~m}$ \\
\hline
\end{tabular}

Berdasarkan Tabel 1 diketahui bahwa air tanah di wilayah UNP kampus Air Tawar sudah dapat ditemukan pada kedalaman 6 $\mathrm{m}$ hingga kedalaman $9 \mathrm{~m}$.

\section{METODE PENELITIAN}

Penelitian dasar bersifat deskriptif ini menggunakan Ares Multielectrode sebagai instrumen utama. Penelitian dilakukan di UNP kampus Air Tawar dengan jumlah lintasan pengukuran sebanyak 4 lintasan seperti ditunjukkan pada Tabel 2.
Tabel 2. Data Koordinat Geografis dan Titik Sounding Setiap Lintasan Pengukuran.

\begin{tabular}{|c|c|c|}
\hline Lintasan & Koordinat & Sounding \\
\hline $\begin{array}{l}1 \\
\text { FIS) }\end{array}$ & $\begin{array}{l}00^{0} 53^{\prime} 41,6^{\prime \prime} \mathrm{LS} \\
100^{0} 20^{\prime} 59,2^{\prime \prime} \mathrm{BT} \\
\text { sampai } \\
00^{0} 53^{\prime} 46,5^{\prime} \mathrm{\prime} \mathrm{LS} \\
100^{0} 21^{\prime} 00,4^{\prime \prime} \mathrm{BT}\end{array}$ & $\begin{array}{l}00^{0} 53^{\prime} 44,0^{\prime \prime} \mathrm{LS} \\
100^{0} 20^{\prime} 79,8^{\prime \prime} \mathrm{BT} \\
\text { (depan Jurusan } \\
\text { Geografi) }\end{array}$ \\
\hline $\begin{array}{l}2 \\
\text { (Gerbang } \\
\text { UNP-FT) }\end{array}$ & $\begin{array}{l}00^{0} 53^{\prime} 52,7^{\prime \prime} \mathrm{LS} \\
100^{0} 21^{\prime} 02,6^{\prime \prime} \mathrm{BT} \\
\text { sampai } \\
00^{0} 53^{\prime} 53,5{ }^{\prime} \mathrm{\prime} \mathrm{LS} \\
100^{0} 21^{\prime} 03,1^{\prime \prime}\end{array}$ & $\begin{array}{l}00^{0} 533^{\prime} 53,1^{\prime \prime} \mathrm{LS} \\
100^{0} 21^{\prime} 02,8^{\prime \prime} \mathrm{BT} \\
\text { (depan Bank } \\
\text { Nagari UNP) }\end{array}$ \\
\hline $\begin{array}{l}3 \text { (FIK - } \\
\text { Lab. } \\
\text { Biologi) }\end{array}$ & $\begin{array}{l}00^{0} 53^{\prime} 55,2^{\prime \prime} \mathrm{LS} \\
100^{0} 20^{\prime} 50,6^{\prime \prime} \mathrm{BT} \\
\text { sampai } \\
00^{0} 53^{\prime} 42,7^{\prime}{ }^{\circ} \mathrm{LS} \\
100^{0} 20^{\prime} 50,5^{\prime} \mathrm{BT}\end{array}$ & $\begin{array}{l}00^{0} 533^{\prime} 48,99^{\prime} \mathrm{LS} \\
100^{\circ} 20^{\prime} 50,6{ }^{\prime} \mathrm{BT} \\
\text { (Lapangan FIK) }\end{array}$ \\
\hline $\begin{array}{l}4 \text { (Balai } \\
\text { Bahasa-- } \\
\text { Mesjid Al } \\
\text { Azhar) }\end{array}$ & $\begin{array}{l}00^{0} 53^{\prime} 58,0^{\prime \prime} \mathrm{LS} \\
100^{0} 21^{\prime} 01,6^{\prime \prime} \mathrm{BT} \\
\text { sampai } \\
00^{0} 53^{\prime} 53,5^{\prime} \mathrm{\prime S} \\
100^{0} 21^{\prime} 03,1^{\prime \prime} \mathrm{BT}\end{array}$ & $\begin{array}{l}00^{0} 53^{\prime} 55,7^{\prime \prime} \mathrm{LS} \\
100^{0} 21^{\prime} 02,3 \text { 'BT } \\
\text { (dekat Mesjid } \\
\text { Al Azhar) }\end{array}$ \\
\hline
\end{tabular}

Penelitian ini diawali dengan melakukan survei ke daerah penelitian untuk menentukan lintasan pengukuran yang akan dilakukan dan mengetahui geologi daerah penelitian. Tahap selanjutnya adalah melakukan pengukuran dengan langkah kerja sebagai berikut:

1. Mengukur lintasan pengukuran sesuai dengan panjang lintasan dan spasi elektroda yang digunakan.

2. Menanam elektroda pada setiap spasi elektroda yang telah ditentukan.

3. Menghubungkan kabel elektroda pada lintasan tadi dan baterai dengan Ares Multielectrode.

4. Mengaktifkan Ares Multielectrode.

5. Memastikan kondisi baterai terisi minimal $85 \%$.

6. Memasukkan input data.

7. Melakukan pengukuran.

8. Data yang diperoleh langsung tersimpan pada Ares Main unit.

Data yang tersimpan pada Ares Main unit didownload menggunakan komputer windows $X P$. Data tersebut kemudian diolah menggunakan software Res2dinv 
dengan inversi Robust Constraint 0,001. Hasil pengolahan data adalah penampang model 2D bawah permukaan bumi yang mengandung kedalaman dan nilai tahanan jenis.

Data yang telah diolah kemudian diinterpretasikan dengan cara membandingkan nilai tahanan jenis yang diperoleh dari data olahan dengan tabel tahanan jenis dan dibandingkan juga dengan kondisi geologi daerah penelitian, sehingga diperoleh suatu kesimpulan berupa batuan dasar penyusun lapisan bawah permukaan bumi beserta kedalaman dan nilai tahanan jenisnya.

\section{HASIL PENELITIAN}

\section{Lintasan 1 (FE - FIS)}

Pengukuran di Lintasan 1 merupakan pengukuran secara otomatis dengan panjang lintasan $155 \mathrm{~m}$ dan spasi elektroda $5 \mathrm{~m}$. Gambar 2 menunjukkan hasil pengolahan data Lintasan 1 menggunakan software Res2dinv dengan inversi Robust Constraint 0,001.

Titik Sounding

$00^{0} 53^{\prime} 44,0^{\prime \prime} \mathrm{LS}$ dan $100^{\circ} 20^{\prime} 79,8^{\prime \prime}$ 'BT



Gambar 2. Penampang Model 2D Lintasan 1 (FE - FIS) dengan titik sounding $00^{0} 53$ '44,0'LS dan $100^{0} 20^{\prime} 79,8$ 'BT (depan Jurusan Geografi)

Berdasarkan Gambar 2 diketahui bahwa daerah di bawah sekitar titik sounding $00^{0} 53^{\prime} 44,0$ '"LS dan $100^{0} 20^{\prime} 79,8^{\prime \prime}$ BT terdapat beberapa lapisan batuan. Lapisan paling atas yaitu dari permukaan hingga kedalaman 3,68 m memiliki nilai tahanan jenis $85,8-513$
$\Omega \mathrm{m}$. Lapisan ini diinterpretasikan sebagai Alluvium dan Sands. Menurut Telford et al (1976:455) Alluvium dan Sands memiliki rentangan nilai tahanan jenis $10-800 \Omega \mathrm{m}$.

Selanjutnya di bawah lapisan Alluvium dan Sands terdapat lapisan yang memiliki nilai tahanan jenis $62,65-85,8$ $\Omega \mathrm{m}$ pada kedalaman 3,68 - 4,62 $\mathrm{m}$ dan diinterpretasikan sebagai Sandstones. Sandstones memiliki rentangan nilai tahanan jenis $1-6,4 \times 10^{8} \Omega \mathrm{m}$ (Telford $e t$ al. 1976: 455). Kedalaman berikutnya yaitu 4,62 - 5,76 m terdapat lapisan yang memiliki nilai tahanan jenis 13,29 - 62,65 $\Omega \mathrm{m}$. Lapisan ini diinterpretasikan sebagai Clays. Clays memiliki rentangan nilai tahanan jenis $1-100 \Omega \mathrm{m}$ (Telford et al. 1976: 455).

Lapisan warna biru tua hingga biru muda memiliki nilai tahanan jenis 0,89 13,29 $\Omega \mathrm{m}$. Lapisan ini berada pada kedalaman $5,76-18,05 \mathrm{~m}$ dan diinterpretasikan sebagai Groundwater. Groundwater memiliki rentangan nilai tahanan jenis $0,5-300 \Omega \mathrm{m}$. Berdasarkan data kedalaman sumur air tanah pada Tabel 1 diketahui kedalaman sumur air tanah di sekitar lintasan ini adalah $6 \mathrm{~m}$. Hal ini menunjukkan bahwa interpretasi data penelitian ini benar, karena mengacu pada data kedalaman sumur tersebut diketahui bahwa kedalaman pipa sumur di sekitar lintasan ini adalah $6 \mathrm{~m}$ dimana posisi pipa tersebut diletakkan sedikit lebih dalam daripada kedalaman Groundwater agar air dapat ditemukan. Sementara berdasarkan hasil penelitian ini, Groundwater ditemukan pada kedalaman 5,76 m.

Lapisan berikutnya ditemukan lagi Clays dan Sandstone secara berurutan dengan masing-masing kedalaman 18,05 19,72 m dan 19,72 - 21,4 m. Selanjutnya terdapat lapisan Alluvium dan Sands pada kedalaman 21,4-25,2 m.

Lapisan terakhir adalah lapisan dengan nilai tahanan jenis $513-622 \Omega \mathrm{m}$. Lapisan ini diduga merupakan lapisan batuan dasar yang terdapat pada kedalaman lebih dari 25,2 m. Batuan dasar tersebut 
diduga merupakan batuan dasar jenis Andesite. Menurut Telford et al (1976: 454) Andesite memiliki rentangan nilai tahanan jenis $1,7 \times 10^{2}-4,5 \times 10^{4} \Omega \mathrm{m}$.

\section{Lintasan 2 (Gerbang UNP - FT)}

Lintasan 2 memiliki panjang lintasan $155 \mathrm{~m}$ dan spasi elektroda $5 \mathrm{~m}$. Pengukuran yang dilakukan pada lintasan ini merupakan pengukuran secara otomatis. Hasil pengolahan data Lintasan 2 menggunakan software Res2dinv inversi Robust Constraint 0,001 berupa penampang 2D ditunjukkan pada Gambar 3.

Titik Sounding

$00^{0} 53^{\prime} 53,1^{\prime \prime} \mathrm{LS}$ dan $100^{\circ} 21^{\prime} 02,8^{\prime}$ 'BT

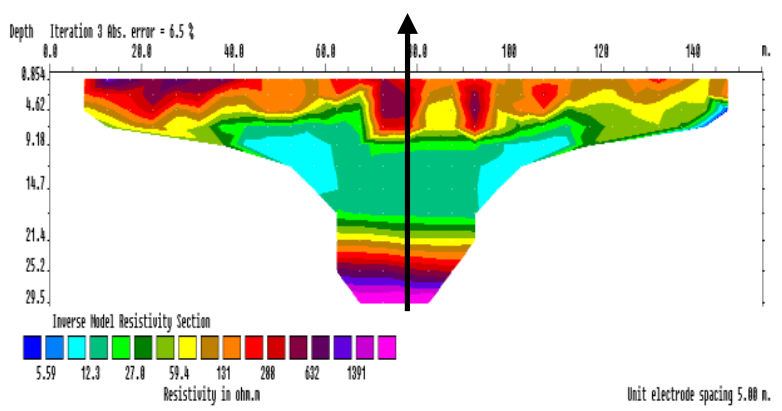

Gambar 3. Penampang Model 2D Lintasan 2 (Gerbang UNP - FT) dengan titik sounding $00^{0} 53^{\prime} 53,1$ '"LS dan $100^{0} 21^{\prime} 02,8^{\prime \prime}$ BT (depan Bank Nagari UNP)

Berdasarkan Gambar 3 diketahui bahwa di bawah titik sounding $00^{0} 53$ '53,1"LS dan $100^{0} 21$ '02,8"BT terdapat lapisan dengan nilai tahanan jenis 95,2 - $632 \Omega \mathrm{m}$ dan diinterpretasikan sebagai Alluvium dan Sands. Alluvium dan Sands ditemukan mulai dari permukaan hingga kedalaman 6,9 m. Lapisan warna kuning tampak berada di bawah lapisan Alluvium dan Sands. Lapisan ini terdapat pada kedalaman 6,9-8,04 m dengan nilai tahanan jenis $59,4 \quad-\quad 95,2 \Omega \mathrm{m} \quad$ dan diinterpretasikan sebagai Sandstones.

Kedalaman berikutnya yaitu $8,04-$ 19,72 m memiliki nilai tahanan jenis 12,3 $59,4 \Omega \mathrm{m}$. Lapisan ini diinterpretasikan sebagai Clays. Lapisan selanjutnya ditemukan lagi Sandstone serta Alluvium dan Sands pada masing-masing kedalaman 19,72 - 21,4 m dan 21,4-25,2 m. Lapisan terakhir adalah lapisan pada kedalaman lebih dari 25,2 $\mathrm{m}$ dengan nilai tahanan jenis yang cukup tinggi yaitu $632-2150 \Omega \mathrm{m}$. Lapisan ini diduga merupakan lapisan batuan dasar jenis Andesite.

Lintasan ini juga ditemukan adanya Groundwater, namun berada pada posisi yang agak jauh dari titik sounding yaitu di posisi elektroda 42,5 - 62,5 $\mathrm{m}$ pada kedalaman 8,04 - 14,7 $\mathrm{m}$ dan posisi elektroda 92,5 - 112,5 m pada kedalaman $8,04-112,5 \mathrm{~m}$. Sementara titik sounding berada pada posisi elektroda 77,5 m. Groundwater pada lintasan ini memiliki nilai tahanan jenis $2,79-12,3 \Omega \mathrm{m}$. Berdasarkan data kedalaman sumur air tanah pada Tabel 1 diketahui bahwa kedalaman sumur air tanah di sekitar lintasan ini adalah $9 \mathrm{~m}$. Hal ini menunjukkan bahwa interpretasi data penelitian ini benar dimana kedalaman air tanah (Groundwater) pada penelitian ini adalah 8,04 m, sementara kedalaman sumur air tanah pada lintasan ini adalah $9 \mathrm{~m}$. Hal ini dianggap benar karena kedalaman pipa sumur diletakkan sedikit lebih dalam daripada kedalaman air tanah agar air tanah dapat diperoleh.

\section{Lintasan 3 (FIK - Lab. Biologi)}

Pengukuran yang dilakukan di Lintasan 3 merupakan pengukuran gabungan secara otomatis dan manual dengan panjang lintasan $425 \mathrm{~m}$ sehingga diperoleh kedalaman yang lebih dalam yaitu lebih dari $104 \mathrm{~m}$. Gambar 4 menunjukkan hasil pengolahan data Lintasan 3 menggunakan software Res2dinv dengan inversi Robust Constraint 0,001 berupa penampang model 2D bawah permukaan bumi. 
Titik Sounding

$00^{0} 53$ '48,9'LS dan $100^{\circ} 20$ '50,6”BT

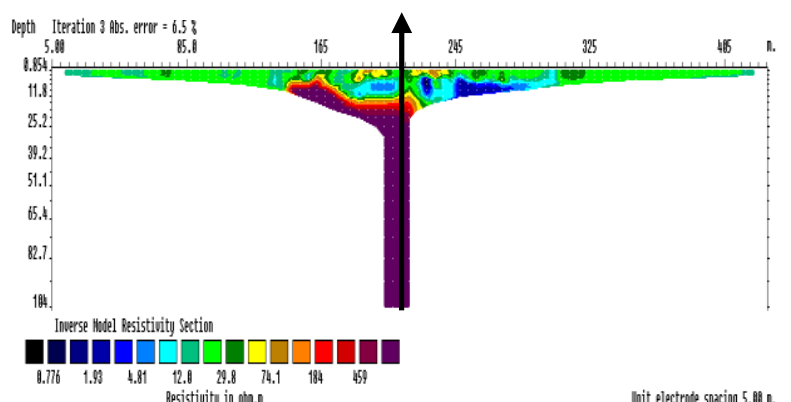

Gambar 4. Penampang Model 2D Lintasan 3 (FIK - Lab. Biologi) dengan titik sounding $00^{0} 53$ ' 48,9 '"LS dan $100^{\circ} 20^{\prime} 50,6^{\prime \prime}$ BT (Lapangan FIK)

Berdasarkan Gambar 4 diketahui bahwa terdapat lapisan dengan nilai tahanan jenis sangat rendah yaitu 8,405$51,95 \Omega \mathrm{m}$ di bawah titik sounding $00^{0} 53^{\prime} 48,9$ 'LS dan $100^{\circ} 20^{\prime} 50,6$ 'BT. Lapisan ini diduga merupakan lapisan Sands yang ditemukan mulai dari permukaan hingga kedalaman 11,8 m. Selanjutnya terdapat lapisan dengan nilai tahanan jenis $0,776-8,405 \Omega \mathrm{m} \quad \mathrm{di}$ kedalaman $5,23-14,48 \mathrm{~m}$ dan diinterpretasikan sebagai Groundwater. Berdasarkan hasil survei pada Tabel 1 diketahui bahwa Groundwater di lintasan ini ditemukan pada kedalaman $6 \mathrm{~m}$. Hal ini sesuai dengan hasil interpretasi data penelitian ini.

Lapisan dengan nilai tahanan jenis 51,95 - 74,1 $\Omega \mathrm{m}$ terdapat pada kedalaman $9,62-11,8 \mathrm{~m}$. Lapisan ini diduga merupakan lapisan Sandstones. Lapisan warna orange hingga merah keunguan berada di bawah lapisan Sandstones. Lapisan ini memiliki nilai tahanan jenis 74,1 - 596,5 $\Omega \mathrm{m}$ dan diinterpretasikan sebagai Alluvium. Alluvium ditemukan pada kedalaman 11,8 - 21,85 m. Lapisan terakhir adalah lapisan dengan nilai tahanan jenis 596,5 - $734 \Omega \mathrm{m}$ pada kedalaman lebih dari $21,85 \mathrm{~m}$. Lapisan ini ditafsir merupakan lapisan batuan dasar jenis Andesite.

\section{Lintasan 4 (Balai Bahasa - Mesjid Al Azhar)}

Lintasan 4 memiliki panjang lintasan $155 \mathrm{~m}$ dan spasi elektroda $5 \mathrm{~m}$. Pengukuran di lintasan ini merupakan pengukuran secara otomatis dengan titik sounding $00^{0} 53^{\prime} 55,7$ ' LS dan $100^{0} 21^{\prime} 02,3$ ' BT seperti yang terlihat pada Gambar 5 .

\section{Titik Sounding \\ $00^{0} 533^{\prime} 55,7^{\prime \prime}$ LS dan $100^{0} 21^{\prime} 02,3^{\prime \prime}$}

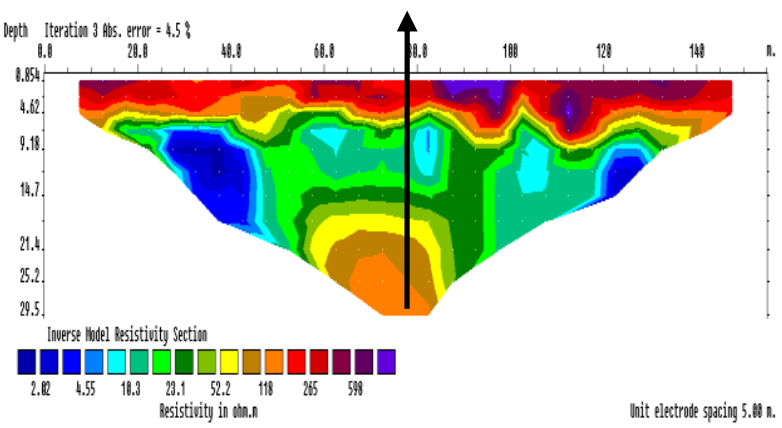

Gambar 5. Penampang Model 2D Lintasan 4 (Balai Bahasa - Mesjid Al Azhar) dengan titik sounding 00 53'55,7' LS dan $100^{0} 21^{\prime} 02,3$ ” BT (dekat Mesjid Al Azhar)

Berdasarkan Gambar 5 dapat diketahui bahwa di sekitar titik sounding $00^{0} 53$ '55,7'LS dan $100^{\circ} 21$ '02,3'BT terdapat lapisan dengan nilai tahanan jenis 191,5 - $931 \Omega \mathrm{m}$ mulai dari permukaan hingga kedalaman 4,62 m. Lapisan ini diinterpretasikan sebagai Sands. Lapisan warna kuning memiliki nilai tahanan jenis $52,2-85,1 \Omega \mathrm{m}$ terdapat di kedalaman 4,62 - 6,9 m. Lapisan ini diduga merupakan lapisan Sandstones. Selanjutnya lapisan warna hijau diinterpretasikan sebagai lapisan Clays dengan nilai tahanan jenis $10,3-52,2 \Omega \mathrm{m}$. Clays terdapat menyebar di sela-sela batuan pada kedalaman 6,9 $18,05 \mathrm{~m}$.

Lapisan yang terdapat pada kedalaman 6,9 - 11,94 m memiliki nilai tahanan jenis $1,01-10,3 \Omega \mathrm{m}$. Lapisan ini diinterpretasikan sebagai Groundwater. Hal ini sesuai dengan data kedalaman sumur pada Tabel 1 yang menyatakan bahwa kedalaman sumur di lintasan ini adalah 8 
m. Pipa sumur harus diletakkan lebih dalam beberapa meter dari kedalaman air tanah yang sebenarnya agar air tanah dapat diperoleh. Hal ini yang membuktikan bahwa interpretasi data ini benar.

Lapisan Sandstone juga ditemukan lagi di lapisan bawah, tepatnya pada kedalaman 18,05 - 21,4 m. Lapisan terakhir yaitu kedalaman lebih dari 21,4 m memiliki nilai tahanan jenis 85,1 - 191,5 $\Omega$ m. Lapisan ini diinterpretasikan sebagai Alluvium. Berdasarkan interpretasi data di atas diketahui bahwa pada lintasan ini tidak ditemukan adanya batuan dasar. Diduga batuan dasar berada pada lintasan ini berada pada kedalaman lebih dari 29,5 m.

\section{PEMBAHASAN}

Berdasarkan hasil analisa data diketahui bahwa rentangan nilai tahanan jenis batuan dasar paling tinggi terdapat pada Lintasan 2 yaitu $632-2150 \Omega \mathrm{m}$ di sekitar titik sounding $00^{0} 53^{\prime} 53,1$ 'LS dan $100^{0} 21^{\prime} 02,8$ 'BT, sedangkan kedalaman batuan dasar yang paling dalam terdapat pada Lintasan 3 tepatnya di sekitar titik sounding $00^{0} 53^{\prime} 48,9$ ' $L S$ dan $100^{0} 20^{\prime} 50,6$ 'BT. Lintasan 3 mampu melakukan pengukuran hingga kedalaman lebih dari $104 \mathrm{~m}$ karena pengukuran di lintasan ini menggabungkan pengukuran secara otomatis dan manual. Lintasan 1,2 dan 4 hanya melakukan pengukuran secara otomatis karena banyaknya bangunan yang menghalangi lintasan ini sehingga kabel elektroda tidak dapat direntangkan dan lintasan pengukuran menjadi lebih pendek.

Berdasarkan hasil interpretasi data diketahui bahwa batuan dasar di UNP kampus Air Tawar memiliki nilai tahanan jenis yang cukup tinggi yaitu antara 513 $2150 \Omega \mathrm{m}$. Nilai tahanan jenis yang tinggi tersebut disebabkan karena batuan dasar memiliki nilai porositas dan permeabilitas yang rendah. Nilai porositas yang rendah menyebabkan batuan dasar bersifat kurang porus dan memiliki sedikit pori-pori sehingga kemungkinan arus listrik dapat mengalir pada batuan dasar sangat kecil.
Nilai permeabilitas yang rendah juga menyebabkan arus listrik sulit mengalir karena air sebagai penghantar arus listrik sulit melewati batuan dasar.

Umumnya batuan dasar pada penelitian ini ditemukan pada lapisan paling bawah yaitu kedalaman lebih dari $21,85 \mathrm{~m}$ dan $25,2 \mathrm{~m}$, tepatnya di sekitar titik sounding. Batuan dasar tersebut menjadi dasar bagi lapisan-lapisan batuan yang berada di atasnya. Berdasarkan jenis batuan yang terdapat di atas lapisan batuan dasar, diperkirakan bahwa batuan dasar ini semakin kompak pada kedalaman yang lebih dalam. Artinya semakin menuju permukaan batuan dasar semakin cepat mengalami pelapukan. Hal ini dibuktikan dengan nilai tahanan jenis lapisan batuan yang berada di atas lapisan batuan dasar lebih rendah daripada nilai tahanan jenis batuan dasar. Batuan-batuan yang terdapat diatas lapisan batuan dasar diduga merupakan hasil pelapukan dari batuan dasar.

Batuan dasar yang terdapat di UNP kampus Air Tawar diinterpretasikan sebagai batuan Andesite. Menurut Telford et al (1976: 454) Andesite memiliki rentangan nilai tahanan jenis $1,7 \times 10^{2}-$ $4,5 \times 10^{4} \Omega \mathrm{m}$. Berdasarkan geologi Kota Padang diketahui bahwa Kota Padang terutama wilayah Air Tawar didominasi oleh Alluvium yang terdiri dari lanau, pasir (Sands) dan kerikil yang mengendap akibat aliran air. Alluvium juga merupakan hasil rombakan batuan Andesite yang berasal dari gunung api. Batuan Andesite yang mengalami pelapukan akan membentuk batuan-batuan baru diatas lapisannya. Berdasarkan hasil interpretasi data di atas diketahui bahwa batuan-batuan baru tersebut adalah Alluvium, Sands, Sandstones dan Clays.

Hasil penelitian ini yaitu informasi tentang kedalaman, nilai tahanan jenis dan jenis batuan dasar diharapkan dapat dijadikan pertimbangan dalam perencanaan pembangunan di UNP kampus Air tawar. Selain itu diharapkan juga dapat dijadikan 
acuan bagi penelitian selanjutnya baik dibidang Geologi maupun bidang Geofisika lainnya yang berkaitan dengan batuan dasar.

\section{KESIMPULAN}

Berdasarkan hasil penelitian dari empat lintasan pengukuran di UNP kampus Air Tawar, diketahui bahwa terdapat batuan dasar di sekitar titik sounding $00^{0} 53^{\prime} 44,0$ '"LS dan $100^{\circ} 20^{\prime} 79,8^{\prime \prime}$ 'BT pada Lintasan 1 dan Lintasan 2 pada titik sounding $00^{0} 53$ ' 53,1 'LS dan $100^{0} 21^{\prime} 02,8^{\prime}$ " BT dengan masing-masing nilai tahanan jenis $513-622 \Omega \mathrm{m}$ dan $632-2150 \Omega \mathrm{m}$ pada kedalaman yang sama yaitu lebih dari 25,2 m. Lintasan 3 juga terdapat batuan dasar di sekitar titik sounding 00 03 '48,9'"LS dan $100^{0} 20^{\prime} 50,6$ " BT dengan nilai tahanan jenis $596,5-734 \Omega \mathrm{m}$ pada kedalaman lebih dari 21,85 m. Lintasan 4 dengan titik sounding $00^{0} 53$ '55,7" LS dan $100^{0} 21$ '02,3" BT tidak ditemukan adanya batuan dasar, diduga batuan dasar pada lintasan ini terdapat pada kedalaman lebih dari 29,5 m. Batuan dasar yang ditemukan pada penelitian ini diinterpretasikan sebagai batuan dasar jenis Andesite yang menjadi dasar batuan bagi lapisan batuan di atasnya.

\section{UCAPAN TERIMA KASIH}

Ucapan terima kasih disampaikan kepada Bapak Drs. Akmam, M.Si dan Ibu Fatni Mufit, S.Pd, M.Si atas ilmu dan bimbingannya dalam menyelesaikan penelitian ini. Terima kasih juga kepada Bapak Drs. Mahrizal, M.Si sebagai Kepala Laboratorium Geofisika, Jurusan Fisika, FMIPA, UNP. Terima kasih kepada DP2M Dikti sebagai sponsor penelitian ini melalui PKM 2012. Terima kasih juga kepada Elvi Novia S, Nelvira Rizalmi, Edi Kurnia, S.Si, Elsi Ariani, S.Si, Sesri Santurima, S.Si, Nofri Hardisal, Yogi Refiyon dan tim geolistrik 2009 atas bantuan teknis selama pengambilan data. Terima kasih kepada Bapak Tunsri Febrison dan Bapak Ahmad
Syamsuardi atas bantuan perbaikan alat sehingga penelitian ini dapat diselesaikan.

\section{DAFTAR PUSTAKA}

Akmam. (2004). "Existence of Spring in Batulimbak Village Simawang Kecamatan Rambatan Kabupaten Tanahdatar". Jurnal Prosiding Seminar PPD Forum HEDS 2004 Bidang MIPA, ISBN 979-95726-7-3. Hlm 593-608.

Dinas Energi dan Sumber Daya Mineral Provinsi Sumatera Barat. (2012). Peta Geologi Kota Padang. Padang.

Gutmanis, Jon. (2010). "Hydrocarbon Production From Fractured Basement Formation". Jurnal. Geoscience Limited Versi 9. Hlm. 1-40.

Hanang Samodra. (2008). "Geologi Batuan Dasar Gunung Ciremai Jawa Barat”. Jurnal Geologi Indonesia 4(5). Hlm. 279-287.

Li, Chuanfeng. Wang, Yongji. Deng, Zhixiang, dan Wu, Hao. (2009). "Adaptive Dynamic Inversion Robust for BTT Missile Based on Wavelet Neural Network)". Jurnal. Proc of SPIE Vol. 7496. Hlm 1-10.

Marescot, Laurent. (2009). Electrical Surveying. Swiss: University of Fribourg.

Moch Munir (1995). Geologi dan Mineralogi Tanah. Malang: Pustaka Jaya.

Reynolds, J.M. (1997). An Introduction to Applied and Environmental Geophysics. New York: Jhon Geophysicsin Hidrogeological and Wiley and Sons Ltd.

Sircar, Anirbid. (2004). "Hydrocarbon Production from Fractured Basement Formations". Jurnal. Current Science. Vol.87. No.2. Hlm 147-151.

Telford, W.M. Geldart, L.P, Sheriff R.E and Keys, D.A. (1976). Applied Geophysics. USA: Cambridge University Press. 